FELIPE ROCHA DEIAB ${ }^{1}$

\title{
O ALARGAMENTO DO CONCEITO DE IMPOSSIBILIDADE NO DIREITO DAS OBRIGAÇÕES: A INEXIGIBILIDADE E A FRUSTRAÇÃO DO FIM DO CONTRATO/ THE EXTENDING OF THE CONCEPT OF LAW FAILURE OF OBLIGATIONS: THE UNENFORCEABILITY AND THE FRUSTRATION OF THE END OF THE CONTRACT.
}

Resumo: A teoria contratual clássica criou um método de repartição dos riscos do contrato, estabelecendo como hipóteses de exoneração do devedor apenas a força maior e o caso fortuito, que atingem a todos e não apenas ao devedor (impossibilidade absoluta). Todavia, a impossibilidade absoluta revelou-se insuficiente para a resolução de todos os problemas práticos do direito das obrigações. É necessário, pois, que se discuta o "alargamento do conceito de impossibilidade". Este estudo pretende apresentar, em linhas gerais, a inexigibilidade do cumprimento da prestação e a frustração do fim do contrato, dois institutos do direito contratual contemporâneo que foram consagrados pela Reforma do BGB.

Palavras-chave: Obrigações - Impossibilidade absoluta - Alargamento da impossibilidade - Frustração do fim do contrato - Inexigibilidade.

Abstract: The classical theory of contract has created a risk-sharing system for the parties. According to this system, an obligation should always be performed, except if it became impossible for everybody and not only for the debtor. Thus, a deep discussion about how contractual risks should be shared by the parties is necessary. In this way, there are two relevant issues at stake: a new legal conception for the impossibility of performance, in order to extend the respective field of application (impracticability and frustration of purposes), as incorporated by a recently-edited law about contracts in Germany: Gesetz zur Modernisierung des Schuldrechts.

Key words: Obligations - Impossibility - Enlargement of impossibility - Frustration of purposes - Impracticability.

\footnotetext{
${ }^{1}$ Mestre em Direito Civil pela Universidade do Estado do Rio de Janeiro (UERJ), Professor do Centro de Estudos e Pesquisa em Direito da Universidade do Estado do Rio de Janeiro (CEPED - UERJ), Procurador do Tribunal de Contas do Estado do Rio de Janeiro e Advogado no Rio de Janeiro.
} 
O alargamento do conceito de impossibilidade no Direito das Obrigações: a inexigibilidade e a frustração do fim do contrato.

Sumário: 1. Introdução: a tradicional distribuição dos riscos nos contratos sinalagmáticos. 2 . $O$ alargamento do conceito de impossibilidade. 2.1. Antecedentes: o caso da venda de automóveis (Reichsgericht, 1920). 2.2. O alargamento da impossibilidade no BGB, após a Reforma de 2001 e as cláusulas gerais de impossibilidade relativa: a inexigibilidade (Unzumutbarkeit): a) obrigações de dar; b) obrigações de fazer. 2.2.1. Impossibilidade relativa e relacionais obrigacionais duradouras. 2.2.2. Casuística: a) Caso Alerse S.R.L. c. Carrefour Argentina S/A (CNCiv., Sala M, 13/10/97); b) Caso José Morandera S.A. v. Nobleza Piccardo S.A. (CNCom., sala D, 22/05/01). 3. A frustração do fim do contrato (Zweckstörung). 3.1. Pressupostos da frustração do fim do contrato. 3.1.1. Exteriorização e relevância da causa final. 3.1.2. Incidência nos contratos onde estiver presente a nota da correspectividade (bilaterais). 3.1.3. Incidência nos contratos de execução diferida e nos contratos de duração. 3.1.4. Inimputabilidade da frustração do fim do contrato à parte que a suscita. 3.2. Casuística. 3.2.1. Inglaterra: a) Paradine vs. Jane, 1647; b) Taylor vs. Caldwell, 1863; c) os casos da coroação ("coronation cases"): 1) Krell vs. Henry; 2) Chandler v. Webster; 3) Herne Bay Steamboat Company v. Hutton. 3.2.2. França: Caso da Diligência Paris-Rouen, 1843. 3.2.3. Alemanha: Caso do imposto sobre o aguardente, 1888 . 3.2.4. Espanha: Casos envolvendo projetos de edificação e os planos de ordenação urbana. 3.3. Semelhanças e diferenças entre a frustração do fim do contrato e outros institutos. 3.3.1. Frustração do fim do contrato e caso fortuito ou força maior. 3.3.2. Frustração do fim do contrato e excessiva onerosidade superveniente (teoria da imprevisão). 3.3.3. Frustração do fim do contrato e erro. 3.3.4. Frustração do fim do contrato e vício redibitório. 3.3.5. Frustração do fim do contrato e lesão. 3.3.6. Frustração do fim do contrato e inexigibilidade (Unzumutbarkeit). 3.3.7. Frustração do fim do contrato e obtenção do propósito prático por outros meios. 3.4. Efeitos da frustração do fim do contrato. 4. Comentários finais: uma ressalva necessária. 


\section{Introdução: a tradicional distribuição dos riscos nos contratos sinalagmáticos ${ }^{2}$.}

De acordo com a teoria contratual clássica, o devedor da obrigação só se exonera de responsabilidade na ocorrência de um determinado fato, imprevisível e irresistível, qualificado como hipótese de caso fortuito ou força maior, que impede o cumprimento da obrigação devida, seja quem for o devedor.

A teoria contratual clássica sempre concebeu o conceito de impossibilidade como absoluto (porque não comporta a avaliação das peculiaridades do caso concreto, sendo genérica) e objetivo (porque atinge a todos que possam ocupar a mesma posição jurídica do devedor). De impossibilidade relativa e subjetiva jamais se poderia cogitar, à luz do pensamento civilístico tradicional, porque o risco é inerente às operações econômicas. Pensar de modo diverso faria ruir "todo o Direito Privado, o processo executivo e o direito das falências". 3

Com base nessas premissas é que foi concebida a repartição contratual dos riscos nos contratos sinalagmáticos ${ }^{4}$, ainda hoje vigente. A regra geral é a de que o titular do interesse sempre sofre os riscos inerentes à respectiva posição jurídica. Assim, por exemplo, se a coisa que o vendedor deve entregar ao comprador for atingida por um raio e destruir-se ou tiver a sua utilidade econômica reduzida antes da tradição, abrem-se duas hipóteses: ou se resolve a obrigação, já que é dado ao comprador enjeitá-la, ou este pode exigir um abatimento do preço (Código Civil, arts. 234, 235 e 492). Semelhantemente, se passa com a obrigação de restituir: se a coisa dada pelo locador (credor) se perder sem culpa do locatário (devedor), é o credor que sofre o prejuízo. Res perit domino, já diziam os romanos.

Para as obrigações de fazer, a teoria tradicional também sempre só conferiu exoneração de responsabilidade ao devedor nos casos de impossibilidade absoluta $^{5}$ (Código Civil, art. 247), de modo que, apenas nas hipóteses de caso fortuito ou força

\footnotetext{
${ }^{2}$ Para um panorama geral da distribuição e alocação dos riscos no contrato, cf. o interessante trabalho de Mousseron. Jean Marc. La gestion des risques par le contrat. In: Revue Trimestrielle de Droit civil, $n$. 3. Paris: Sirey, Juillet/Septembre 1988, p. 481-504. No direito brasileiro, cf. a preciosa contribuição de GOMES, Orlando. Obrigações. 6 ed. Rio de Janeiro: Forense, 1981, p. 221-233.

${ }^{3}$ CordeIro, Antônio Manuel Menezes. Da boa-fé no Direito Civil. Coimbra: Almedina, 2001, p. 1011.

${ }^{4} \mathrm{O}$ alargamento da impossibilidade não se aplica aos contratos aleatórios, porquanto nestes a assunção dos riscos é um elemento essencial da relação jurídico-obrigacional.

5 Andrade, Manuel A. Domingues de. Teoria Geral da Relação Jurídica, vol. II. 1. ed., 9a reimpr. Coimbra: Almedina, 2003, p. 331.
} 
maior, o contrato pode ser resolvido, sem que se imponha ao devedor o pagamento de perdas e danos.

Todas essas regras atinentes à distribuição dos riscos do contrato consubstanciam normas dispositivas, e, portanto, afastáveis pela vontade das partes. Então, nas relações contratuais é lícito que se estabeleça uma repartição desses riscos completamente diversa daquela prevista em lei. Assim é que, v. g., a cláusula de atualização monetária afasta o risco do credor da obrigação pecuniária de ver a prestação em dinheiro, que lhe é devida, corroer-se pela depreciação da moeda.

É preciso entender, contudo, que a distribuição dos riscos do contrato, da forma como preconizada pela teoria contratual clássica, está a merecer uma reformulação.

Pela teoria contratual clássica, cada parte procura, de certa forma, promover o que se chama de "distribuição contratual do risco", que consiste em determinar, por intermédio de cláusulas inseridas no instrumento contratual, como se dará a distribuição dos riscos entre os contraentes.

Como salientado por PATRICK S. ATIYAH, quando há possibilidade de alteração das circunstâncias negociais, o contrato serve justamente ao propósito de afastar os riscos, fazendo-os incidir sobre uma das partes ou repartindo-os entre elas. Cada um dos contraentes pode assumir o risco, afastá-lo ou partilhá-lo, de acordo com os interesses em comum. E não apenas o próprio risco é suscetível de previsão. Também as próprias consequiências dos fatos que integram o risco contratual podem ser dimensionadas pelas partes. $^{6}$

Desse modo, em suma, pode-se dizer que, de acordo com a teoria contratual clássica, (i) todo risco é previsível, exceto o caso fortuito; (ii) todo risco pode ser previsto em uma cláusula contratual que o contemple; (iii) todo risco pode ser assumido, deslocado ou compartilhado; (iv) o titular assume o risco da frustração de um interesse concreto ou negocial ${ }^{7}$. A idéia central é a de que o contrato é um instrumento jurídico que promove a distribuição dos riscos econômicos entre os contratantes. Por isso, se as partes deixaram de prever modo diverso de distribuição de riscos daquele

\footnotetext{
${ }^{6}$ ATYIAH, Patrick. The rise and fall of freedom of contract. Oxford: Clarendon Press, 1979, p. 202-205. ${ }^{7}$ ITURRASPe, Jorge Mosset; FAlCón, Enrique M.; PIEDECASAS, Miguel. A. La frustrácion del contrato y la pesificación. Buenos Aires: Rubinzal-Culzoni, 2002, p. 38 e segs.
} 
previsto em lei, é justamente este que se aplica à relação contratual, independentemente de quaisquer considerações quanto ao sacrifício imposto ao devedor. ${ }^{8}$

\section{O alargamento do conceito de impossibilidade.}

Apesar do relativo prestígio de que goza a tradicional distribuição do risco, tão arraigada no sistema romano-germânico, já há algum tempo vem sendo travada na doutrina e na jurisprudência ampla discussão a respeito das insuficiências desse modelo de repartição dos riscos contratuais. Tal discussão centra-se no chamado "alargamento da impossibilidade", uma ampliação do conceito tradicional de impossibilidade, que identifica como hipóteses de exoneração do devedor não apenas a força maior e o caso fortuito, mas também a inexigibilidade do cumprimento da prestação (Unzumutbarkeit) e a frustração do fim do contrato (Zweckstörung). ${ }^{9}$

\subsection{Antecedentes: o caso da venda de automóveis (Reichsgericht, 1920).}

Na Alemanha, o debate a respeito das causas de exoneração da responsabilidade contratual vem sendo travado desde o advento do final da Primeira Grande Guerra, momento em que, pressionado pela dificílima situação econômica que o País atravessava, o Tribunal do Império (Reichsgericht) passou a identificar como contrária à cláusula geral de boa-fé objetiva a exigência de cumprimento da prestação pelo devedor, mesmo que se lhe impusesse sacrifício extremo, acima dos limites de seus

\footnotetext{
${ }^{8}$ Aguiar JR., Ruy Rosado de. Extinção dos Contratos por Incumprimento do Devedor - Resolução (de acordo com o Novo Código Civil). 2. ed. (rev. e atual.). Porto Alegre: Aide, 2004, p. 99.

9 Pode-se, por isso mesmo, afirmar que o alargamento da impossibilidade está ligado ao princípio do favor debitoris, que impõe a observância, na relação obrigacional, não só dos interesses do credor, mas também do devedor, de modo a se facilitar o cumprimento da prestação. Conquanto não haja um enunciado expresso do princípio entre nós, inúmeras regras de nossa legislação vigente permitem identificar a existência do favor debitoris: a limitação dos juros moratórios não-convencionados (Código Civil, art. 406); a regra da imposição da menor onerosidade possível ao devedor, na execução civil (Código de Processo Civil, art. 620); o direito do devedor de alterar, por motivo grave, o local de pagamento (Código Civil, art. 329); a presunção de inexistência de solidariedade (Código Civil, art. 265) etc. Sobre o princípio do favor debitoris no direito brasileiro, cf. ALvES, José Carlos Moreira. O favor debitoris como princípio geral de direito. In: Revista Brasileira de Direito Comparado, $\mathrm{n}^{\circ}$ 26, p. 03-23, $1^{\circ}$ semestre, 2004 e MOTA, Maurício. A proteção decorrente do favor debitoris como princípio geral do direito das obrigações no ordenamento jurídico brasileiro. Quaestio Iuris, v. 3, p. 49-108, 2006.
} 


\section{Quaestio Iuris}

esforços (Einrede der Existenzvernichtung, "exceção da ruína") ${ }^{10}$. Surgia, assim, a doutrina da inexigibilidade de conduta diversa (Unzumutbarkeit), que, curiosamente, experimentaria maior desenvolvimento no direito penal ${ }^{11}$.

Dentre todas as decisões proferidas pelo Reichsgericht a propósito da chamada inexigibilidade, uma, proferida em 22.10.1920, chama a atenção em especial, porque, como bem ressalta ANTÔNIO MANUEL MENEZES CORDEIRO, "coloca problemas dogmáticos insolúveis até hoje”. ${ }^{12}$

O caso envolvia a venda de um automóvel por 12.000 marcos alemães. O réuvendedor recusara-se a efetuar a transferência de propriedade do veículo, sob a alegação de que, por força de alteração das circunstâncias negociais alheias à sua vontade custos da operação econômica - o preço teria de ser elevado para 17.000 marcos. Em linha de princípio, o Tribunal julgador entendeu que admitir-se a alteração do contrato por conta de modificações nos custos seria o fim da segurança jurídica, acrescentando que, na venda, o risco do preço é do vendedor. Mas, diante de uma determinada manifestação do réu-vendedor, informando a existência de uma série de contratos dessa natureza que houvera celebrado com inúmeros compradores, e da demonstração de que o efeito multiplicador de decisões, que a tais compradores garantissem o preço inicial, poderia ocasionar-lhe um prejuízo da ordem de 800.000 marcos, ocasionando a sua conseqüente ruína, o Tribunal remeteu o processo às instâncias ordinárias para que avaliassem a veracidade de tais declarações. ${ }^{13}$

\subsection{O alargamento da impossibilidade no BGB, após a Reforma de 2001 e as cláusulas gerais de impossibilidade relativa: a inexigibilidade (Unzumutbarkeit).}

\footnotetext{
10 LORENZ, Werner. Contract Modification and Change of Circumstances. In: BEATSON, Jack \& Friedmann, Daniel (Ed.). Good Faith and Fault in Contract Law. Oxford: Clarendon Press, 1995 (reprinted in 2002), p. 369.

${ }^{11}$ CORDEIRO, Antônio Manuel Menezes. Op. cit., p. 1019.

${ }^{12}$ Ibidem, p. 1009. Cf. ainda LARENZ, Karl. Base del negocio jurídico y cumplimiento de los contratos (traducción de Carlos Hernandez Rodriguez). Madrid: Editorial Revista de Derecho Privado, 1956, p. 101.

${ }^{13}$ Poder-se-ia argumentar, em tese, que o caso em apreço comportaria a aplicação da teoria da excessiva onerosidade. Mas tal argumento não se sustenta, na medida em que a excessiva onerosidade superveniente só encontra campo de aplicação nos contratos de execução continuada e de trato sucessivo. Basta atentar-se, a título de ilustração, para o art. 478 do Código Civil vigente. Assim tb. a doutrina (Tepedino, Gustavo; Barboza, Heloísa Helena; e Moraes, Maria Celina Bodin de. Código Civil Interpretado conforme a Constituição da República: Parte Geral e Obrigações (arts. $1^{\circ}$ a 420). 1 . ed. Rio de Janeiro: Renovar, 2006, p. 130).
} 
Passados mais de 80 anos desde aquela polêmica decisão, a Reforma do BGB, de 2001, consagrou e positivou a teoria da impossibilidade relativa (ou subjetiva), que está prevista, em termos gerais, no vigente $\$ 275$ n.1 do BGB, segundo o qual: "a pretensão ao cumprimento da prestação não subsiste, se for impossível para o devedor ou para todos" $" 14$.

Afasta-se, assim, o velho princípio de que somente, e tão-somente, a impossibilidade absoluta de cumprimento da prestação (impossibilidade objetiva, isto é, que acomete a todos e não apenas ao obrigado) exonera o devedor da responsabilidade contratual.

a) Obrigações de dar.

Seguindo esse caminho, o n. 2 do $\$ 275$ prevê uma cláusula geral de impossibilidade relativa, ao estabelecer que:

"o devedor pode recusar a prestação sempre que esta exija um esforço que esteja em grave desproporção diante do interesse do credor na prestação, considerados o conteúdo da relação obrigacional e a regra da boa-fé. Na determinação dos esforços imputáveis ao devedor é também de ter em conta se o impedimento da prestação deve ser imputado a este último." $" 15$ (destaques acrescentados).

O dispositivo alberga aquelas hipóteses em que a prestação que incumbe ao devedor ainda seria possível, mas exigir que este viesse a cumpri-la lhe acarretaria um esfoço desproporcional. ANTÔNIO MANUEL MENEZES CORDEIRO esclerece que o exemplo clássico na matéria, dado por HECK, é o da prestação de entrega de um anel, que caiu no fundo arenoso de um lago: "seria possível drenar o lago e pesquisar

\footnotetext{
14 "Der Anspruch auf Leistung ist ausgeschlossen, soweit diese für den Schuldner oder für jedermann unmöglich ist.".

15 “(2) Der Schuldner kann die Leistung verweigern, soweit diese einen Aufwand erfordert, der unter Beachtung des Inhalts des Schuldverhältnisses und der Gebote von Treu und Glauben in einem groben Missverhältnis zu dem Leistungsinteresse des Gläubigers steht. Bei der Bestimmung der dem Schuldner zuzumutenden Anstrengungen ist auch zu berücksichtigen, ob der Schuldner das Leistungshindernis zu vertreten hat."
} 


\section{Quaestio Iuris}

vol.05, $\mathrm{n}^{\circ}$ 02. ISSN 1516-0351

adequadamente na areia, numa operação de milhões. Haveria, todavia e perante a boa-

fé, um grave desequilíbrio perante o interesse do credor. "16

O caso paradigmático, aqui, foi uma decisão proferida pelo Reichsgericht em $1904^{17}$. Confira-se.

Um comprador encomendou a um moinho uma grande quantidade de um tipo especial de farinha, produzida conforme uma receita secreta. Sem qualquer culpa do vendedor, o moinho foi destruído por um incêndio antes da entrega das sacas de farinha. Em termos estritamente legais, o vendedor seria responsável pelo cumprimento da obrigação, porquanto, tratando-se de típica obrigação de gênero, os riscos recaem exclusivamente sobre o devedor, até o momento da concentração (segundo dispunha o $\S 279$ do BGB, então vigente ${ }^{18}$ ).

A situação do vendedor ainda agravava-se no caso concreto, porque uma grande quantidade daquela farinha havia sido enviada a outro comprador, um pouco antes do incêndio. Mas o Tribunal do Império alemão entendeu que o vendedor, naquela hipótese, não estava obrigado a obter de outros fornecedores a farinha especial pretendida pelo comprador. Para a Corte, o evento fortuito havia dificultado tanto o cumprimento da obrigação de entregar as sacas de farinha que, levando-se em

\footnotetext{
${ }^{16}$ CORDEIRO, Antônio Manuel Menezes. A Modernização do direito das obrigações. Revista da Ordem dos Advogados de Portugal, vol. II, abr./2002. Disponível em: http://www.oa.pt/Conteudos/Artigos/detalhe artigo.aspx?idc=31559\&idsc=13744\&ida=13767. Acesso em 15.09.2006. Registre-se que, para o célebre Professor d'além Mar, “a fórmula do $\$ 275 / 2$ pretendeu operar uma clivagem entre uma impossibilidade fáctica e a 'mera' impossibilidade económica, conhecida como limite do sacrifício e que apenas poderia ser integrada no instituto da alteração das circunstâncias, agora codificado no $\$ 313$ BGB. A pedra de toque estaria em que, na impossibilidade de facto do $\$ 275 / 2$, não estariam em causa as possibilidades do devedor, ao contrário do que sucederia no § 313: a impossibilidade determinar-se-ia mercê de um crasso desequilíbrio, inadmissível perante a boafé. As dificuldades de interpretação são patentes: a casuística será decisiva. Pela nossa parte, o alargamento da impossibilidade à 'impossibilidade de facto', operada pelo BGB/2002, visa a depuração da alteração das circunstâncias. A impossibilidade deve ser tomada em sentido sócio-cultural: não físico ou naturalístico. Daí que, impossível, seja o que, como tal e na concreta relação existente com o credor, se apresente. $O$ devedor comum não estará obrigado a drenar um lago para recuperar o anel; a empresa de drenagem contratada para o efeito está-lo-á, como é evidente."

${ }^{17}$ EbKe, Werner F. \& STEINHAUER, Bettina M. The Doctrine of Good Faith in German Contract Law. In: BEATSON, Jack and FrIEDMANN, Daniel. (Ed.). Op. cit, p. 180.

${ }^{18}$ A norma constante do $\S 279$, revogada, dispunha que "se o objeto da obrigação é definido apenas pelo gênero, o devedor permanece responsável pelo cumprimento, ainda que nenhuma culpa lhe possa ser atribuída, na medida em que a prestação puder ser obtida pela entrega de bens do mesmo gênero" [Ist der geschuldete Gegenstand nur der Gttung nach bestimmt, so hat der Sschulder, solange die Lestiung aus der Gattung möglich ist, sein Unvermögen zur Leistung auch dann zu vertreten, wenn ihm ein Verschulden nicht zur Last fällt], norma semelhante à do art. 246 do Código Civil de 2002 ("Antes da escolha, não poderá o devedor alegar perda ou deterioração da coisa, ainda que por força maior ou caso fortuito").
} 
consideração os padrões do comércio, tal obrigação tornara-se quase impossível. Assim, impunha-se liberar o devedor do cumprimento do contrato.

Essa decisão do Reichsgericht representou um forte temperamento da regra segundo a qual o "gênero nunca perece", inerente às obrigações de dar coisa incerta.

Como se sabe, na obrigação de dar coisa certa, a individualização da coisa já ocorre no momento da celebração do contrato (como sucederia, por exemplo, numa hipotética compra-e-venda do quadro "Guernica", de Picasso). Nas obrigações de dar coisa incerta, passa-se de forma diversa: quando da celebração do contrato, só é possível identificar a coisa pelo gênero e pela quantidade. A individualização da coisa só ocorrerá no chamado momento da concentração (é o que se dá, e.g., quando um restaurante encomenda a uma vinícola cem garrafas de vinho tinto chileno).

Pois bem. A regra geral é a de que o gênero nunca perece; é a coisa que perece. Como, até o momento da concentração, a obrigação é de gênero, o devedor permanece obrigado enquanto o gênero continuar existindo, de sorte que, mesmo na hipótese de caso fortuito ou força maior, o devedor é obrigado a entregar ao credor o que o contrato determina, na quantidade e espécie ajustadas. Tal regra está presente, inclusive, na norma constante do art. 246 do nosso Código Civil.

Contudo, no julgamento do caso, o Reichsgericht entendeu que, apesar dessa regra geral, segundo a qual o devedor permanece obrigado perante o credor enquanto o gênero existir, o proprietário do moinho não estava obrigado a obter sacas de farinha da mesma espécie daquela encomendada pelo comprador, tendo em vista que a dificuldade para cumprir tal obrigação a tornava praticamente impossível para todo comerciante.

Criava, assim, o Tribunal do Império alemão uma hipótese de impossibilidade relativa, idônea a liberar o devedor do cumprimento da prestação, conquanto esta ainda fosse física e juridicamente possível ${ }^{19}$. Ali se estava diante de hipótese de inexigibilidade (Unzumutbarkeit), hoje prevista no BGB ( $\$ 275$, n.2).

\section{b) Obrigações de fazer.}

De grande relevância também foi a alteração realizada no $§ 275$, do BGB, para incluir a chamada impossibilidade relativa de fato (\$275, n.3, tradução livre):

\footnotetext{
${ }^{19}$ EBKe, Werner F. \& STEINHAUER, Bettina M. Op. cit., p. 181.
} 
"O devedor pode ainda recusar a prestação quando deva realizar pessoalmente a prestação e esta, ponderados os impedimentos do devedor em relação ao interesse do credor na prestação, não possa lhe ser exigida." ${ }^{20}$ (destaques acrescentados).

Trata-se, aqui, da impossibilidade das prestações pessoais (nas obrigações de fazer infungíveis), de que é exemplo a situação da cantora que, estando com o filho gravemente enfermo, deixa de comparecer ao espetáculo. É mais uma tentativa de se procurar amenizar os rigores da civilística clássica, segundo a qual a impossibilidade da prestação de fazer, caso atinja apenas o devedor, não o exonera da responsabilidade pelo descumprimento do contrato.

Eis aí o que se pode chamar de ponderação do direito obrigacional: passa-se a levar em consideração o interesse não só do credor, mas também do devedor. Ao mesmo tempo, não se sacrifica o interesse do credor: a cláusula geral do $§ 275$, n. 3 permite que, no caso concreto, sejam ponderados os interesses de ambos. Pela teoria tradicional, essa ponderação jamais seria cabível: da cantora, no exemplo dado, poderia o credor exigir perdas e danos pelo descumprimento do contrato.

\subsubsection{Impossibilidade relativa e relações obrigacionais duradouras.}

É clássica a lição de GIORGIO OPPO ${ }^{21}$, segundo a qual os contratos podem ser divididos em três diferentes categorias, de acordo com a influência que o tempo exerce sobre a execução do contrato.

Se o interesse das partes reside em que o adimplemento de uma prestação (ou de ambas) ocorra em um momento determinado, isto é, em que a execução do contrato só se dê a partir de certo lapso de tempo, estar-se-á diante de um contrato de execução diferida. Nessa hipótese, o tempo marca a distância entre a celebração e o adimplemento do contrato. Como exemplo dessa categoria de contrato pode-se mencionar a compra-e-venda com pagamento futuro.

A uma segunda categoria pertencem os contratos cuja execução implica o transcorrer de um determinado decurso de tempo. É o que ocorre, v.g., no contrato de

\footnotetext{
20 “(3) Der Schuldner kann die Leistung ferner verweigern, wenn er die Leistung persönlich zu erbringen hat und sie ihm unter Abwägung des seiner Leistung entgegenstehenden Hindernisses mit dem Leistungsinteresse des Gläubigers nicht zugemutet werden kann."

${ }^{21}$ OPPO, Giorgi. I contratti di durata. In: Scriti giuridici, Padova: CEDAM, 1992, vol. III, p. 209.
} 
empreitada: a realização de uma obra ou reforma não se dá, de acordo com a ordem natural das coisas, de forma instantânea, mas sim ao longo de certo decurso de tempo.

A terceira categoria abrange os contratos em que o interesse das partes reside justamente em que a execução se protraia no tempo, para a satisfação de uma necessidade duradoura. Nesses casos, o adimplemento não ocorre a partir de um determinado momento, nem tampouco depende de uma atividade que só se completa com o passar do tempo. Na verdade, nesse tipo de contrato, as partes pretendem que $a$ execução se protraia no tempo. Nessa categoria enquadram-se os contratos de trato sucessivo (em que as obrigações se renovam periodicamente, como na locação, no fornecimento de mercadorias etc) e os contratos de execução continuada (em que as obrigações são, por sua essência, projetadas para o futuro, como ocorre no contrato de sociedade, no contrato de concessão de serviços públicos, de agência, de representação comercial etc).

Há uma diferença bastante acentuada, como se vê, entre, de um lado, os contratos de execução diferida e, de outro, os contratos de execução continuada e os de trato sucessivo.

Os contratos de execução continuada e de trato sucessivo compõem a categoria dos contratos de duração em sentido estrito.

Como salienta ANTÔNIO JUNQUEIRA DE AZEVEDo, nesses contratos o tempo faz parte da causa final do contrato ${ }^{22}$, ou seja, o fim que as partes têm em mira projeta-se para um fato futuro 23 .

$\mathrm{Na}$ Alemanha, essas relações jurídicas são denominadas de relações obrigacionais continuativas (Dauernschuldverhältnisse), ou ainda de contratos de duração (Dauernverträge). Nessa espécie de contrato, além de o tempo influir diretamente sobre a causa, outra característica lhe é marcante: a maior consideração às expectativas da parte que participa do vínculo, o que gera maior intensidade dos deveres de cooperação, por força da incidência do princípio da boa-fé objetiva ${ }^{24}$.

\footnotetext{
${ }^{22}$ AzEVEDO, Antônio Junqueira de. Natureza jurídica do Contrato de consórcio. Classificação dos atos jurídicos quanto ao número de partes e quanto aos efeitos. Os contratos relacionais. Contratos de duração. Alteração das circunstâncias e onerosidade excessiva. Sinalagma e resolução contratual. Resolução parcial do contrato. Função social do contrato. Revista dos Tribunais, São Paulo, v. 807, p. 123, fev. 2005.

${ }^{23}$ Idem. Negócio Jurídico: Existência, Validade e Eficácia. São Paulo, Saraiva, 2000, p. 138.

${ }^{24}$ Ibid. p. 214.
} 
Independentemente da denominação que se use, certo é que, quando se alude a contrato de execução continuada, ou a contrato de longa duração não se está a se referir a uma expressão de cunho genérico ou atécnica. Cuida-se de uma categoria específica de relações contratuais marcada por uma característica essencial: as partes desejam que a execução se dê ao longo do tempo.

No campo dos contratos de duração, a Reforma do BGB foi ainda mais longe. Em lugar da velha regra da excessiva onerosidade, inseriu no BGB a chamada "perturbação da base objetiva do negócio" (Störung der Geschäftsgrundlage), dando nova redação ao §313, nos seguintes termos (tradução livre):

"Se as circunstâncias, que constituem a base do contrato, se alterarem radicalmente depois da celebração do contrato, de forma que se possa concluir que as partes não o teriam celebrado ou o teriam celebrado com outro conteúdo caso tivessem previsto tais alterações, pode a parte pleitear a adaptação do contrato, se, levadas em consideração todas as circunstâncias do caso concreto, e em especial, a repartição contratual ou legal dos riscos, não se lhe puder exigir que permaneça na relação contratual." (destaques acrescentados).

Nota-se, que, muito mais do que a alteração no equilíbrio econômico, a norma encartada no vigente $\$ 313$ do BGB leva em conta a alteração da partilha dos riscos da relação contratual, em perspectiva mais consentânea com a atual realidade econômica.

Primeiramente, o que chama a atenção é a semelhança entre o $§ 313$ e o disposto no 275 , n.2, supracitado. A diferença básica entre os dois preceitos está em que, enquanto naquele, há um favor debitoris, ou seja, uma exceção, no sentido técnico ${ }^{25}$, atribuída ao devedor, para recusar o cumprimento da prestação que lhe incumbe, é dado - não só ao devedor, mas a todos os contraentes - o direito de pleitear a adaptação do

\footnotetext{
${ }^{25} \mathrm{O}$ conceito de exceção remete à ideia de defesa que não pode ser conhecida de ofício, pelo juiz, competindo ao interessado o ônus de suscitá-la. Nos dizeres de PONTES DE MIRANDA, "por mais cumprida e completamente provada que esteja, nos autos, a exceção, se não foi oposta, isto é, alegada como exercício (= comunicação de conhecimento mais comunicação de vontade), nada pode o juiz no sentido de atender a ela. (...) Do conceito de exceção é ineliminável que dependa do demandado, ou devedor, exercê-la." (MIRANDA, Francisco Cavalcanti Pontes de. Tratado de Direito Privado, tomo VI. Rio de Janeiro: Borsoi, 1957, p. 11).
} 
contrato (e não a faculdade [rectius: exceção] de se recusar ao cumprimento da respectiva prestação) ${ }^{26}$.

Por outro lado, também salta aos olhos a substituição da idéia de revisão contratual pela de adaptação contratual. A adaptação do contrato encontra aplicabilidade justamente nos contratos de duração, porque é nessa espécie de relações contratuais que se verifica, com maior freqüência, a necessidade de flexibilizar as cláusulas e condições do negócio.

O conceito de adaptação do contrato possui um sentido lato e um outro, estrito. Em sentido lato, adaptar o contrato é modificá-lo, diante das alterações das circunstâncias negociais presentes no momento da celebração. Em sentido estrito, adaptar o contrato significa modificá-lo, de modo a permitir que as partes possam dele extrair, na prática, as legítimas expectativas (Vertrauensumstände) de cada uma delas, objetivamente consideradas ${ }^{27}$.

\footnotetext{
${ }^{26}$ Registre-se que, para ANTÔNIO MENEZES CORDEIRO, “a fórmula do § 275/2 pretendeu operar uma clivagem entre uma impossibilidade fáctica e a 'mera' impossibilidade económica, conhecida como limite do sacrifício e que apenas poderia ser integrada no instituto da alteração das circunstâncias, agora codificado no $\$ 313$ BGB. A pedra de toque estaria em que, na impossibilidade de facto do $\$$ 275/2, não estariam em causa as possibilidades do devedor, ao contrário do que sucederia no § 313: a impossibilidade determinar-se-ia mercê de um crasso desequilíbrio, inadmissível perante a boa-fé. As dificuldades de interpretação são patentes: a casuística será decisiva. Pela nossa parte, o alargamento da impossibilidade à "impossibilidade de facto", operada pelo BGB/2002, visa a depuração da alteração das circunstâncias. A impossibilidade deve ser tomada em sentido sócio-cultural: não físico ou naturalístico. Daí que, impossível, seja o que, como tal e na concreta relação existente com o credor, se apresente. $O$ devedor comum não estará obrigado a drenar um lago para recuperar o anel; a empresa de drenagem contratada para o efeito está-lo-á, como é evidente." Op. cit. (destaques acrescentados).

${ }^{27}$ ANDREAS NELLE classifica em três categorias as formas de adaptação do contrato: (i) adaptação ipso jure ou automática; (ii) a que decorre do exercício de um direito formativo ou de uma decisão judicial de natureza constitutiva; (iii) a que decorre de um acordo de vontades. No primeiro caso, estabelece-se um mecanismo de adaptação automático. É o caso, v.g., das cláusulas de atualização monetária, que estabelecem de antemão que os preços estão indexados a certos índices, sem necessidade de que as partes tornem a renegociar alterações futuras de preço. A segunda hipótese abrange os casos de revisão judicial do contrato por intermédio do exercício dos direitos potestativos conferidos pela lei, tanto os que dependem de uma sentença constitutiva que os reconheça no caso concreto (v.g., a norma constante do art. 317 do Código Civil brasileiro), quanto aqueles que podem ser exercidos por uma das partes independentemente de qualquer ação (e.g., o $\$ 315$ (I) do $B G B$, o qual, regulando o direito da parte de determinar o conteúdo de uma prestação, dispõe que "se cabe a um dos contratantes determinar a prestação, na dúvida, supõe-se que tal determinação será feita equitativamente.") Na terceira categoria, encontram-se os casos em que as próprias partes acordem em renegociar o contrato (é o que sucede, por exemplo, quando a parte que não é prejudicada pela onerosidade excessiva aceita rever os termos e condições do contratos para torná-lo eqüitativo, na forma do prevê o art. 479 do Código Civil). NELLE, como se percebe, confere à adaptação do contrato um sentido mais amplo, a ponto de abarcar até mesmo a resolução e a revisão do contrato por excessiva onerosidade (NELLE, Andreas. Neuverhandlungspflichten: Neuverhandlungen zur Vertragsanpassung und Vertragsergänzung als. Gegenstand von Pflichten und Obliegenheiten. München: C.H.Beck'sche, 1994, p. 17). Na doutrina brasileira, no mesmo sentido, cf. GAVAZZONI, Adriana. A renegociação e a adaptação do contrato internacional. 1. ed. Curitiba: Juruá, 2006, p. 31.
} 
Nos dizeres de FIKENTSCHER, essas legítimas expectativas constituem o conjunto de circunstâncias cuja presença e permanência são fundamentais para que as partes obtenham os resultados práticos que perseguem, a tal ponto de que o próprio propósito prático do contrato (a causa do contrato) depende da continuidade, ao longo do tempo, de tais circunstâncias, continuidade essa que as partes podem fazer valer com base na cláusula geral de boa-fé objetiva ${ }^{28}$.

Sucede que o risco de frustração dessas legítimas expectativas aumenta consideravelmente nos contratos de longa duração (Dauernverträge), já que o tempo aumenta os riscos da operação econômica.

Atento a essa realidade, o legislador alemão, novamente valendo-se da técnica das cláusulas gerais, estabeleceu no $\S 314$, n.1, o alargamento do conceito de impossibilidade no âmbito das relações obrigacionais duradouras (Dauernschuldvehältnisse), permitindo ao devedor denunciar o contrato de longa duração, sem, entretanto, deixar de atentar para o interesse do credor. Confira-se:

§314. Denúncia das relações contratuais de longa duração.

Os contratos de execução continuada podem ser denunciados por qualquer uma das partes por justa causa, independentemente de haverse fixado, no contrato, um prazo para a denúncia. Considera-se presente a justa causa quando, levando-se em conta as circunstâncias do caso concreto e ponderando-se os interesses de ambas as partes, não for possível exigir da parte denunciante a continuação do contrato até o seu termo final ou até o advento do início do prazo estipulado no contrato para a rescisão.

Aquele que pretende denunciar o contrato somente poderá fazê-lo se exercer esse direito dentro de um prazo razoável, contado a partir do momento em que teve ciência da justa causa.

A pretensão indenizatória pelos danos causados pela denúncia do contrato não fica prejudicada. ${ }^{29}$ (destaques acrescentados).

${ }^{28}$ FIKENTSCHER, Wolgang. Schuldrecht. 9. Durchgesehene und Ergänzte Auflage. Berlin: Walter de Gruyter, 1997, p. 129.

29 “\$ 314 Kündigung von Dauerschuldverhältnissen aus wichtigem Grund

(1) Dauerschuldverhältnisse kann jeder Vertragsteil aus wichtigem Grund ohne Einhaltung einer Kündigungsfrist kündigen. Ein wichtiger Grund liegt vor, wenn dem kündigenden Teil unter Berücksichtigung aller Umstände des Einzelfalls und unter Abwägung der beiderseitigen Interessen die Fortsetzung des Vertragsverhältnisses bis zur vereinbarten Beendigung oder bis zum Ablauf einer Kündigungsfrist nicht zugemutet werden kann.

(2) Besteht der wichtige Grund in der Verletzung einer Pflicht aus dem Vertrag, ist die Kündigung erst nach erfolglosem Ablauf einer zur Abhilfe bestimmten Frist oder nach erfolgloser Abmahnung zulässig.

(3) Der Berechtigte kann nur innerhalb einer angemessenen Frist kündigen, nachdem er vom Kündigungsgrund Kenntnis erlangt hat.

(4) Die Berechtigung, Schadensersatz zu verlangen, wird durch die Kündigung nicht ausgeschlossen.” 
Como se percebe, o novo dispositivo do BGB previu uma hipótese de denúncia do contrato baseada na dificuldade da parte (dificuldade, portanto, subjetiva) no cumprimento da prestação.

Trata-se, à semelhança do disposto no $\$ 275$, n.2, de mais uma hipótese de inexigibilidade da prestação (Unzumutbarkeit) da parte sobre cujos ombros pesa um sacrifício por demais elevado para cumprir a respectiva prestação, sem que a outra parte fique à míngua da necessária indenização pelos prejuízos causados em virtude da extinção do contrato, fórmula que é muito mais apropriada do que a velha solução do retorno ao status quo ante, adotada, por exemplo, pelo art. 478 do Código Civil de 2002.

É bom que se diga, contudo que o disposto no $\$ 314$ só tem aplicação quando se fizer presente uma justa causa para a denúncia, assim entendido o fato ou ato jurídico que conduz à inexigibilidade de que a parte prossiga na relação contratual duradoura. A aferição, entretanto, da inexigibilidade, depende de uma ponderação dos interesses de todas as partes envolvidas. Quer isso dizer que a denúncia do contrato de longa duração só será cabível até o ponto em que uma das partes perder o interesse prático em manter o vínculo contratual, inclusive na hipótese de ter-se tornado economicamente inviável o prosseguimento do contrato.

Para melhor compreensão do que se está a dizer, vale trazer à baila alguns casos judiciais em que - mesmo à falta de previsão legal expressa - a inexigibilidade foi aplicada a situações concretas, que envolviam relações obrigacionais duradouras.

\subsubsection{Casuística}

a) Caso Alerse S.R.L. c. Carrefour Argentina S/A (CNCiv., Sala M, 13/10/97). ${ }^{30}$

Carrefour Argentina S/A deu em locação a Alerse S.R.L. um estabelecimento destinado ao comércio, situado no Shopping Solei. Posteriormente, circunstâncias não imputáveis às partes (localização geográfica, conjuntura econômica, inauguração de um novo shopping nas proximidades) acabaram por levar ao fechamento de várias empresas no Shopping Solei (que operavam nos setores de comércio, prestação de serviços etc). Houve uma acentuada queda no movimento econômico daquele centro de compras e o

${ }^{30}$ GIANFELICI. Mario Cesar. La frustración del fin del contrato. 1. ed. Buenos Aires: Hammurabi, 2004, p. 163. 


\section{Quaestio Iuris}

vol.05, $\mathrm{n}^{\circ}$ 02. ISSN $1516-0351$

local deixou de atrair os consumidores e o público em geral. A elevada diminuição no volume de vendas levou, afinal, ao completo fracasso do empreendimento.

A empresa locatária, Alerse S.R.L., propôs ação contra Carrefour Argentina S/A, pleiteando a resolução do contrato, além dos danos e prejuízos causados pela “frustração do fim do contrato".

Em primeira instância, julgou-se procedente a demanda, determinando-se a resolução do contrato, e condenando-se o Carrefour a reembolsar à autora as despesas efetuadas com a instalação da empresa no local e a restituir os equipamentos que ali permaneceram. Ambas as partes apelaram da sentença: a locatária, por considerar que o Carrefour deveria ser condenado pelos danos e prejuízos decorrentes do contrato; este, por sua vez, porque sustentava não ser devido qualquer reembolso ou restituição.

No Tribunal de Alçada, confirmou-se a sentença, considerando-se aplicável à espécie a teoria da frustração do fim do contrato. Segundo a Corte, o objetivo determinante e exteriorizado que levara a locatária a celebrar o contrato residia na funcionalidade, na organização e na atração do público proporcionada pela agregação de certas empresas naquele local (Shopping Solei), desempenhando atividades empresariais distintas, tais como serviços de bar e restaurante, exploração de jogos infantis etc.

Por isso, o fracasso do empreendimento, com o fim das atividades empresariais desempenhadas por outros locatários, e a conseqüente perda do poder de atrair o público consumidor, com a sensível queda nas vendas, apesar de não impossibilitar a prestação de responsabilidade do locador, a tornara simplesmente inútil, tomando-se em consideração os interesses do locatário.

O pleito da locatária-autora, para responsabilizar o locador (Carrefour) pelos danos e prejuízos incorridos foi rejeitado pelo Tribunal, sob a fundamentação de que não se tratava de resolução pelo descumprimento do contrato, imputável à parte ré. Não restara comprovada, ademais, a culpa desta quanto ao fracasso do empreendimento.

Relativamente à apelação do Carrefour, entendeu-se que a condenação que lhe fora imposta em primeira instância, para reembolsar os gastos que haviam sido efetuados pela locatária com a instalação no shopping deveria ser mantida, porquanto traduzia uma "justa repartição dos riscos inerentes ao contrato". 
b) Caso José Morandera S.A. v. Nobleza Piccardo S.A. (CNCom., sala D, 22/05/01). ${ }^{31}$

O caso envolveu duas empresas, uma distribuidora, a José Morandera S/A (autora), e uma fabricante de cigarros, a Nobleza Piccardo S.A. (ré), que haviam celebrado um contrato de distribuição com vigência de 47 anos.

A empresa José Morandera S/A, autora, também era distribuidora da Massalín Particulares S.A., tradicional concorrente da Nobleza Piccardo S.A. no mercado de cigarros. Ambas operavam por intermédio de uma rede de 75 distribuidores nãoexclusivos, de forma que cada um desses distribuidores comercializava as marcas de cigarros das duas fabricantes.

Em 1997, a Massalín decidiu, por razões atinentes à natureza do negócio, modificar o sistema de comercialização: selecionou, dentre os 75 distribuidores nãoexclusivos, 29, que passaram a ser exclusivos, denunciando os contratos celebrados com os demais. Dentre os distribuidores não-selecionados estava a autora, José Morandera S.A., à qual a Massalín comunicara a denúncia do contrato em 4 de março de 1997, pagando uma indenização pelas perdas e danos incorridas com a extinção do vínculo contratual.

Poucos dias depois, em 10 de março de 1997, a Nobleza Piccardo S.A. - que também decidira alterar o sistema de distribuição e comercialização das marcas de cigarros que fabricava, nos mesmos moldes da concorrente - comunicou a denúncia do contrato de distribuição celebrado com a José Morandera S.A., com efeitos a partir do dia seguinte, 11 de março daquele ano, sob a fundamentação de que a Massalín destruíra o sistema de comercialização de forma injurídica e intempestiva.

A José Morandera S.A.propôs ação judicial requerendo o pagamento de perdas e danos por parte da Nobleza Piccardo S.A., que, como matéria de defesa, aduziu que a denúncia do contrato ocorrera por razões de força maior: a sobrevinda de uma conduta superveniente e irresistível da sua concorrente, que tornara inviável a manutenção de todos os contratos de distribuição celebrados com as empresas que não haviam sido selecionadas pela Massalín para atuarem como distribuidoras desta.

\footnotetext{
${ }^{31}$ Ibidem, p. 161-162.
} 
A Corte julgadora julgou improcedente o pedido, mas sob fundamentação diversa da que fora aduzida pela ré: considerou que, no caso concreto, não haveria que se cogitar de força maior, mas sim de frustração do fim do contrato ou inexigibilidade. A Corte decidiu que a atitude da Massalín deveria ser considerada como um acontecimento irresistível e imprevisível, prejudicial à Nobleza Piccardo S.A. (ré), que, entretanto, não comprovara a inviabilidade econômica da manutenção do contrato com a autora.

\section{A frustração do fim do contrato (Zweckstörung). ${ }^{32}$}

A frustração do fim do contrato reside precisamente na inexecução de um contrato bilateral, cuja execução avance no tempo, e que, conquanto válido, tem afetada a respectiva causa, tendo por efeito a resolução do contrato (para JORGE MOSSET ITURRASPE, o efeito pode ser também o dever de renegociação do contrato ${ }^{33}$ ).

A frustração dos fins do vínculo contratual é uma das hipóteses de ineficácia do contrato, ao lado da excessiva onerosidade superveniente, das hipóteses de impossibilidade obrigacional absoluta (caso fortuito ou força maior) e da inexigibilidade (esta prevista expressamente no $§ 314$ do BGB), da qual muito se aproxima.

\subsection{Pressupostos da frustração do fim do contrato.}

\subsubsection{Exteriorização e relevância da causa final.}

A causa do contrato é - insista-se - a causa-fim ou causa final, ou seja, os propósitos práticos perseguidos e exteriorizados pelas partes, uma à outra.

Mas não é a perda de qualquer propósito prático que enseja a aplicação da teoria da frustração do fim do contrato. É necessário que a causa seja pertinente ao vínculo contratual. Assim, por exemplo, se um imóvel for locado por um inquilino com a

\footnotetext{
${ }^{32}$ A respeito do tema, cf. Cogo, Rodrigo Barreto. A frustração do fim do contrato. 2005. 287 f. Dissertação (Mestrado em Direito Civil) - Universidade de São Paulo, São Paulo, 2005.

33 ITURRASPE, Jorge Mosset. Contratos conexos. Grupos y redes de contratos. Buenos Aires: Rubinzal-Culzoni, 1999, p. 116-117. Essa conseqüência, entretanto, será rara na prática. Isso porque frustrado o fim do contrato, praticamente não haverá margem de manobra para negociações que venham a atender ao interesse da parte que já não mais pretende prosseguir com a relação contratual. Não existe frustração parcial do fim do contrato: ou o fim contratual desaparece ou permanece.
} 


\section{Quaestio Iuris}

vol.05, $\mathrm{n}^{\circ}$ 02. ISSN 1516-0351

finalidade de assistir a um desfile militar em uma determinada data, é essa a finalidade que surge como elemento integrante da causa. O fato de ocorrer um eclipse lunar na mesma data é irrelevante para efeito de identificar os propósitos práticos e, conseqüentemente, a causa do contrato ${ }^{34}$.

Por outro lado, a ciência dos propósitos práticos pelos contraentes é fundamental para se distinguir a causa do motivo, que é elemento de ordem subjetiva. O propósito prático que compõe a causa é sempre objetivo.

Por isso, para a aplicação da teoria da frustração do fim do contrato, pouco importam os motivos, ou seja, o elemento psíquico ou a intenção dos contraentes. Interessa, isto sim, que seja exteriorizada a utilidade prática que cada parte tinha em vista ao contratar.

Expressa ou até tacitamente, mas sempre de modo inequívoco, os contratantes devem concordar que a utilidade prática "X" é um elemento essencial do negócio "A".

\subsubsection{Incidência nos contratos onde estiver presente a nota da correspectividade (bilaterais).}

A frustração do fim do contrato incide apenas nos contratos onde houver correspectividade, vale dizer, naqueles contratos em que uma das partes obriga-se a dar, fazer, ou não-fazer apenas se a outra parte também se obrigar a uma certa prestação (dar, fazer ou não-fazer), ou seja, nos contratos bilaterais.

A correspectividade, na precisa lição de Maria CELINA Bodin DE MORAES, é “ $a$ relação de interdependência que une as atribuições patrimoniais ligadas por um nexo de causalidade, de modo que uma atribuição é a razão (causa) justificativa da outra". ${ }^{35}$

Embora a doutrina clássica tenha-se debruçado sobre a onerosidade, formulando a conhecida dicotomia entre contratos onerosos e contratos gratuitos, é a correspectividade que qualifica o negócio jurídico.

A onerosidade é um critério acessório (porque incapaz de alterar a identidade funcional da obrigação) e acidental (porque pode estar presente ou faltar, sem que disso resulte a modificação do tipo legalmente previsto), que consiste no equilíbrio entre a

\footnotetext{
${ }^{34}$ GIANFELICI, Mario César. Op. cit, p. 78.

${ }^{35}$ MORAES, Maria Celina Bodin de. O procedimento de qualificação dos contratos e a dupla configuração do mútuo no direito civil brasileiro. Revista Forense, vol. 309, p. 46.
} 
vantagem patrimonial imposta à parte e o respectivo sacrifício econômico. A correspectividade, diferentemente, não exige o equilíbrio entre a prestação e a contraprestação, mas tão-somente a interdependência entre ambas.

$\mathrm{Na}$ realidade, ao contrato gratuito não se contrapõe o contrato oneroso. É a ausência da correspectividade que permite qualificar um contrato como sendo gratuito.

Pense-se, por exemplo, no comodato. O comodante não empresta o bem ao comodatário em função de alguma vantagem. Por isso, seria de todo impensável que o comodatário alegasse que a finalidade do contrato foi afetada pela impossibilidade de consecução do propósito prático que ele tivera em vista. A única finalidade juridicamente relevante, nesse caso, é a liberalidade do comodante. Pouco importa se o bem emprestado não serviu ao propósito prático pretendido pelo comodatário: o negócio jurídico permanece válido e eficaz.

Assim sendo, pode-se afirmar que, nos contratos gratuitos, ao beneficiário não resta outra alternativa a não ser conformar-se com a utilidade prática que essa prestação trará a ele, já que a outra parte não recebe nada em troca. Afinal de conta, em cavalo dado não se olham os dentes!

Conseqüentemente, é certo que a frustração do fim do contrato atinge tãosomente os contratos em que estiver presente a nota da correspectividade. ${ }^{36}$

\subsubsection{Incidência nos contratos de execução diferida e nos contratos de duração.}

A frustração do fim do contrato pode afetar tanto os contratos de execução diferida, como os contratos de duração (assim entendida a categoria que abrange as relações contratuais de trato sucessivo e os chamados contratos de execução continuada).

Nos contratos de execução instantânea, não encontra espaço de aplicação a frustração do fim do contrato, porque esta pressupõe certo transcurso de tempo entre a conclusão do contrato e a alteração das circunstâncias que afetam os propósitos práticos integrantes da causa.

Se a impossibilidade da causa final do contrato já se apresenta na gênese do vínculo, estar-se-á diante de invalidade do contrato por falta de causa (v.g., seguro sem

\footnotetext{
${ }^{36}$ GIANFELICI, Mario César. Op. cit., p. 117.
} 
assunção do risco; compra-e-venda de coisa própria) ou por ilicitude da causa (de que são exemplos o empréstimo feito a jogador para permanecer praticando o vício do jogo; a doação em recompensa por serviços ilícitos e o pagamento de menor preço ao receptador $)^{37}$.

\subsubsection{Inimputabilidade da frustração do fim do contrato à parte que a suscita.}

Se a parte que pleiteia a aplicação da teoria da frustração do fim contrato provocou ou concorreu para a frustração do propósito prático que os contraentes elegeram como elemento essencial do negócio, não é dado a essa parte valer-se da ineficácia do contrato para pleitear a resolução.

Suponha-se, à guisa de ilustração, que alguém procure uma instituição financeira para obter um empréstimo de dinheiro em diversas parcelas para a obtenção de capital de giro. Obtido o empréstimo, o mutuário percebe que, diante das baixas taxas de juros praticadas pelo banco para o mútuo celebrado com aquela finalidade, é mais vantajoso utilizar a quantia emprestada para pagar as suas dívidas próprias, pois se realizasse um empréstimo dessa natureza, a taxa de juros seria muito mais elevada. Posteriormente, o mutuário vê a empresa entrar em declínio, por insuficiência de capital, e pleiteia a resolução do contrato pela frustração do propósito prático.

Ora, se o propósito prático era a obtenção de capital de giro e o mutuário, com o numerário obtido por intermédio do empréstimo, acaba por concorrer para o descumprimento do contrato, assiste ao banco-credor o direito potestativo de resolver o contrato por inadimplemento do mutuário-devedor.

O banco, na hipótese em apreço, em nada concorreu para a frustração da finalidade prática do contrato. Se o mutuário, por conta e risco próprio, desvirtuou o propósito prático do empréstimo, os efeitos da não-consecução do propósito só podem ser a ele cometidos. Em verdade, a frustração do fim do contrato deriva sempre de um fato inimputável aos contratantes.

\subsection{Casuística.}

\footnotetext{
${ }^{37}$ Moraes, Maria Celina Bodin de. A causa dos contratos. Revista Trimestral de Direito Civil, Rio de Janeiro, v. 21, p. 95-120, jan./mar. 2005, p. 110.
} 
$\mathrm{Na}$ seção anterior foram tecidas as necessárias considerações iniciais sobre o conceito e as características da frustração do fim do contrato. Agora, passa-se ao exame de alguns casos práticos retirados da jurisprudência estrangeira. Posteriormente, distinguir-se-á a frustração do fim do contrato de outras figuras.

\subsubsection{Inglaterra}

a) Paradine vs. Jane, $1647 .^{38}$

Jane havia arrendado terras de propriedade de Paradine. Contudo, um príncipe alemão, chamado Rupert, inimigo do Rei da Inglaterra, promoveu uma invasão militar no território do Reino, expulsando Jane das terras arrendadas. Jane, então, deixou de pagar os aluguéis a Paradine, situação que perdurou por quatro anos. Inconformado, Paradine ajuizou uma ação de cobrança contra Jane, que, por sua vez, argumentou que a invasão militar nos terrenos arrendados a impedira de explorá-las economicamente.

O Tribunal (Câmara dos Lordes) deu ganho de causa a Paradine, obrigando Jane a pagar os aluguéis, sob a fundamentação de que quando alguém contrai uma obrigação, deve cumpri-la, independentemente de quaisquer acontecimentos. Jane só poderia ser exonerada do cumprimento do contrato caso houvesse cláusula expressa nesse sentido.

Na verdade, o caso acima retrata uma hipótese de caso fortuito ou força maior. No Direito Inglês, não se admitia a exoneração da responsabilidade contratual sequer em razão da ocorrência de acontecimentos extraordinários e imprevisíveis (ressalvados os eventos da natureza, os chamados acts of God, como tempestades, maremotos, terremotos, furacões etc).

A decisão mencionada serve para demonstrar a força do princípio da obrigatoriedade dos contratos no sistema da Common Law.

Foi a partir do caso Paradine v. Jane que se iniciou o desenvolvimento da teoria da frustração do fim do contrato, com o intuito de amenizar o caráter absoluto das convenções.

b) Taylor vs. Caldwell, $1863 .{ }^{39}$

\footnotetext{
${ }^{38}$ Inteiro teor da decisão disponível em http://www.bailii.org/ew/cases/EWHC/KB/1647/J5.html. Acesso em 19 de julho de 2007.
} 
Caldwell, proprietário de um teatro (music hall) havia celebrado um contrato de locação com Taylor, para a apresentação de quatro grandes concertos. Mas um incêndio, inimputável às partes, destruiu o teatro. Taylor, produtor dos concertos, reclamou uma indenização de Caldwell, baseando sua pretensão, dentre outros casos, em Paradine vs. Jane.

Lord Blackburn julgou improcedente a demanda, sob a fundamentação de que a existência da coisa locada era um fato imprescindível para a execução do contrato e que, como esta pereceu sem culpa do locador, não havia como responsabilizá-lo pelos danos causados à outra parte. O contrato estava, pois, sujeito a uma condição implícita (implied term), segundo a qual as partes estariam liberadas de suas obrigações se a execução do contrato viesse a se tornar impossível sem culpa de qualquer uma das partes. Assim sendo, o locador não estava obrigado a indenizar o locatário, nem deste poderia ser cobrado o valor dos aluguéis.

\section{c) Os casos da coroação (“coronation cases”).}

No ano de 1902, Eduardo VII, filho da Rainha Vitória, ascendeu ao trono. Para comemorar a coroação do novo Rei, foram organizadas duas paradas militares para os dias 26 e 27 de junho e uma revista à Marinha Real, que estava ancorada na Baía de Spithead, no dia 28 de junho. Sucedeu que, no dia 24 de junho, o futuro Rei adoeceu e todos os festejos foram suspensos.

Muitos súditos haviam celebrado contratos de locação de imóveis situados nas proximidades das paradas militares, apenas durante os dias de desfile, para poderem assisti-los de perto. Como tais eventos deixaram de ser realizados nas datas, alguns locatários recusaram-se a pagar o valor dos aluguéis. Chegavam aos tribunais ingleses os casos da coroação (coronation cases).

1) Krell vs. Henry. ${ }^{40}$

\footnotetext{
${ }^{39}$ Inteiro teor da decisão disponível em http://www.bailii.org/ew/cases/EWHC/QB/1863/J1.html. Acesso em 19 de julho de 2007.

${ }^{40}$ Inteiro teor disponível em http://www3.uninsubria.it/uninsubria/allegati/pagine/1438/priv_comp2.pdf. Acesso em 19 de julho de 2007.
} 
Henry, em 17 de junho de 1902, observara um anúncio nas janelas do apartamento de Krell, localizado no número 56 da Pall Mall, no qual Krell informava que o apartamento encontrava-se à disposição de possíveis locatários nos dias 26 e 27 de junho (dias das paradas militares). No dia 20 de junho, Krell e Henry celebraram um contrato de locação do apartamento para os dias do desfile militar. O preço acordado foi de 75 libras, sendo 25 libras à vista, com o saldo restante de 50 libras a ser pago no dia 24. No instrumento contratual, entretanto, não se fez referência à finalidade do contrato (assistir às paradas militares em festejo à coroação do novo Rei).

Na manhã do dia 24, noticiou-se a suspensão dos festejos.

Krell exigiu o pagamento das 50 libras restantes. Henry, a devolução das 25 libras que haviam sido pagas no dia 20.

A Corte julgadora declarou aplicável à espécie os fundamentos da decisão proferida em Taylor vs. Caldwell. Considerou que a finalidade do contrato de locação tinha sido frustrada, decidindo que não era cabível a devolução da quantia que já havia sido paga por Henry, nem o pagamento das 50 libras restantes. O contrato de locação em apreço fora celebrado com a finalidade de que Henry assistisse aos desfiles militares que seriam realizados nos dias 26 e 27.

\section{2) Chandler v. Webster. ${ }^{41}$}

Chandler locou de Webster um imóvel para assistir aos desfiles da coroação, sendo cobrado um aluguel de 141 libras. Com a suspensão dos desfiles, Chandler, que já pagara 100 libras antes de os desfiles serem suspensos, pleiteou em juízo a devolução daquela quantia, ao argumento de que ruíra a consideration $^{42}$ do contrato. $\mathrm{O}$ réulocador, a seu turno, reconveio, pedindo o pagamento integral do valor do aluguel ajustado.

\footnotetext{
${ }^{41}$ Inteiro teor disponível em http://www.a-levellaw.com/caselibary/CHANDLER\%20\%20WEBSTER\%20\%5B1904\%5D\%201\%20KB\%20493\%20\%20CA.doc\#I. Acesso em 19 de julho de 2007.

${ }^{42} \mathrm{O}$ conceito de consideration, típico do direito contratual dos países de Common Law, remete à idéia de uma vantagem ou compensação feita pelo promitente (o contrato sempre é visto como promessa) ou de um sacrifício suportado pelo promissário, sendo elemento constitutivo da bargain (ou seja, do negócio como um todo). A consideration só está presente nos contratos onerosos. É vasta a bibliografia anglosaxã a respeito do tema. Para um panorama geral a respeito da consideration na atualidade, cf. CHENWISHART, Mindy. Consideration: Practical Benefit and the Emperor's New Clothes. In: BEATSON, Jack and Friedmann, Daniel. (Ed.). Good Faith and Fault in Contract Law. Oxford: Clarendon Press, 1995, reprinted in 2002, p. 123-150.
} 
O Tribunal decidiu que, além de não assistir ao autor o direito de reclamar a devolução da parcela do aluguel paga, ele ainda deveria pagar as 41 libras restantes. Os efeitos da frustração, segundo o Tribunal julgador, atingiam tão-somente as prestações futuras pagas, e não as que já haviam vencido.

\section{3) Herne Bay Steamboat Company v. Hutton. ${ }^{43}$}

As autoridades britânicas haviam anunciado que a revista da Marinha Real seria realizada pelo Rei Eduardo VII no dia 28 de junho de 1902, na Baía de Spithead. Hutton alugou um barco de propriedade da companhia Herne Bay Steamboat, com o objetivo de levar algumas pessoas que pagariam para assistir, da embarcação, a revista naval e, ainda, realizar uma excursão pela baía.

Hutton pagou antecipadamente 50 libras, de um aluguel total de 250. Porém, com o anúncio da suspensão do desfile, o barco não zarpou.

A companhia proprietária do barco reclamou o pagamento das 200 libras restantes. Hutton aduziu que a realização da revista naval no dia 28 de junho era condição sine qua non para a celebração do contrato. Como o evento não ocorrera naquela data, a consideration do contrato desaparecera por completo.

Na primeira instância, reconheceu-se que Hutton não estava obrigado a pagar o valor do aluguel restante. O Tribunal, entretanto, reformou a decisão, sob a fundamentação de que, diversamente das locações dos apartamentos próximos ao cortejo, locar um barco para a contemplação da revista da Marinha Real britânica era uma finalidade unilateral de Hutton e não de ambos os contratantes. Quando os proprietários das casas e apartamentos próximos aos desfiles anunciavam a locação de seus imóveis por um ou dois dias, e os locatários aceitavam o preço e as condições do contrato, ambas as partes tinham em mente que a finalidade prática específica daqueles contratos era assistir, de uma perspectiva privilegiada, as paradas militares que se realizariam em virtude da coroação. Mas alugar uma embarcação para se realizar um passeio ou um cruzeiro era a finalidade normal de um contrato de locação dessa natureza, pouco importando o fim específico e determinado do locatário. Naquele caso, concluiu-se que a frota estava na baía, para ser vista. O fato de o Rei não passar em

\footnotetext{
${ }^{43}$ Cf. Herne Bay Steamboat Co v. Hutton [1903] 2 KB 683, 691-692.
} 
revista os navios e a tropa era irrelevante para os fins do contrato, estando, por isso mesmo, dentre os riscos suportados exclusivamente pelo locatário.

\subsubsection{França.}

Caso da Diligência Paris-Rouen, $1843 .^{44}$

No mês de abril de 1842, uma empresa de Paris e outra, de Rouen, celebraram um contrato de exploração dos serviços de transporte por carruagens entre as duas cidades. $\mathrm{O}$ percurso seria realizado em três dias. No ano seguinte, entretanto, inaugurouse a ferrovia Paris-Rouen, que fazia o mesmo trajeto em apenas meio-dia.

A empresa parisiense pleiteou em juízo a resolução do contrato, alegando a perda da finalidade.

Os tribunais acolheram o pedido da empresa de Paris, sob o fundamento de que a inauguração da estrada de ferro representava uma hipótese de caso fortuito ou força maior, da qual resultara a impossibilidade da execução do contrato.

\subsubsection{Alemanha}

Caso do imposto sobre o aguardente, $1888 .^{45}$

A demanda girava em torno dos seguintes fatos: em abril de 1887, o autor havia comprado do réu aguardente de beterraba, o qual deveria ser entregue gradualmente, de agosto a outubro daquele ano. Contudo, em $1^{\circ}$ de agosto daquele ano, entrou em vigor lei do Império Alemão que instituiu elevadíssimo imposto sobre a bebida. O vendedor (réu) tentou fazer a entrega do mês de outubro em barris selados pelo Fisco, para transferir ao comprador a responsabilidade pelo pagamento do imposto. O comprador, entretanto, não admitiu a entrega nessas condições por entender que não haviam sido pactuadas quando da celebração do contrato.

O Reichsgericht não acolheu o pedido do comprador, porque entendeu que o contrato de compra-e-venda de mercadorias, sendo sinalagmático, pressupunha a equivalência entre o preço pago e o bem vendido. Assim, naquele caso, como o valor do imposto era tão elevado que excedia o preço cobrado pelo vendedor, não haveria como

\footnotetext{
${ }^{44}$ GiANFELICI, Mário César. Op. cit, p. 23.

${ }^{45}$ Ibidem, p. 23.
} 


\section{Quaestio Iuris}

se exigir deste o cumprimento do contrato, se tivesse de arcar com o pagamento do imposto.

\subsubsection{Espanha}

Casos envolvendo projetos de edificação e os planos de ordenação urbana. ${ }^{46}$

1) Sentença de 3 de novembro de 1983.

Uma empresa de construção contratara um arquiteto para a elaboração de um projeto de edificação, e a posterior direção dos trabalhos relativos ao erguimento de um prédio multifamiliar, em determinado terreno. A celebração do contrato prescrevia que o arquiteto deveria entregar o projeto até $1^{\circ}$ de dezembro de 1973.

O projeto foi concluído em março de 1974. No dia 23 de abril daquele ano, o arquiteto submeteu o projeto à aprovação do Colégio de Arquitetos, procedimento prévio necessário à obtenção da licença para construir, outorgada pelos órgãos administrativos competentes. Sucede que, na data de 29 de março de 1974, fora aprovado o novo Plano Geral de Ordenação Urbana e Territorial da Comarca de Barcelona, que veio a reduzir em oitenta por cento a área edificável do terreno em que seria executada a construção, o que, conseqüentemente, tornava impossível realizar a obra nos termos do projeto.

$\mathrm{O}$ arquiteto reclamou em juízo o pagamento dos honorários devidos pela elaboração do projeto, ao que se opôs a empresa contratante, sob a fundamentação de que o projeto perdera toda a sua utilidade, não podendo mais ser aproveitado, em função do advento do novo Plano Geral de Ordenação Urbana da Cidade de Barcelona. Além disso, aduziu a ré, o arquiteto não formulara o projeto a tempo.

O Tribunal julgador rejeitou o pedido formulado pelo arquiteto, entendendo que a construção do edifício havia-se tornado impraticável antes mesmo que o projeto fosse aprovado pelo Colégio de Arquitetos. A partir do advento do novo Plano Geral de Ordenação Urbana, o projeto já não mais atendia à finalidade contemplada pela empresa-ré. Como o contrato determinara que ao arquiteto incumbia não só elaborar o projeto, mas também dirigir os trabalhos de edificação, o Tribunal qualificou o contrato como uma locação de obras, que gera uma "obrigação de resultado", qual seja, a entrega

\footnotetext{
${ }^{46}$ Ibidem, p. 30-33.
} 
da obra pronta. Assim, os riscos do projeto deveriam correr por conta exclusiva do arquiteto, até a entrega da obra.

2) Sentença de 9 de dezembro de 1983.

Os autores da ação - arquitetos - haviam sido contratados pelo réu para que elaborassem um projeto destinado à construção de um edifício de apartamentos. No mês de novembro de 1977, os arquitetos contratados apresentaram perante o órgão competente o "Estudo de Detalhes", uma espécie de programa de trabalho, necessário para que as autoridades locais autorizassem a construção no terreno que serviria de base à edificação. Em 23 de fevereiro de 1978, antes de se conhecer a decisão do órgão competente acerca do "Estudo de Detalhes", autores e réu celebraram um contrato para a realização das obras previstas no projeto.

Em 27 de março de 1978, o "Estudo de Detalhes" foi rejeitado pelas autoridades locais, por não estar em conformidade com o Plano de Ordenação Urbana vigente, o que impossibilitava a construção do edifício. No dia 31 de março de 1978, o projeto foi aprovado pelo Colégio de Arquitetos.

Os autores pleitearam em juízo o pagamento dos honorários fixados pelo Colégio de Arquitetos, sustentando que o projeto fora aprovado por aquela instituição, estando à disposição do réu-contratante. Este, por sua vez, aduziu como defesa a inviabilidade da construção prevista no projeto, em virtude da desaprovação deste pelo órgão competente.

O Tribunal rejeitou o pedido formulado pelos arquitetos, dentre outras razões (como defeitos na redação do contrato, imputável exclusivamente aos arquitetos), porque a desaprovação do "Estudo de Detalhes" acarretara a negativa de licença para construir e, conseqüentemente, a impossibilidade de execução da obra. Desse modo, o fim do contrato restara frustrado e a prestação de pagar os honorários se tornara inexigível.

3.3. Semelhanças e diferenças entre a frustração do fim do contrato e outros institutos. 
A frustração do fim do contrato possui semelhanças com outros institutos do direito das obrigações. Há, inclusive, julgados em que se confunde a frustração do fim do contrato com outras figuras.

A autonomia de um instituto, porém, concretiza-se apenas se for possível distingui-lo com clareza de outros. Impende, assim, esclarecer as semelhanças e as diferenças entre a frustração do fim do contrato e outros institutos. Fixadas essas premissas, procurar-se-á diferenciar, dentre os casos práticos mencionados, em quais efetivamente se está diante de frustração do fim do contrato.

\subsubsection{Frustração do fim do contrato e caso fortuito ou força maior.}

O caso fortuito (ou a força maior) leva à resolução do pacto, sendo, portanto, causa de ineficácia superveniente do contrato. A frustração do fim do contrato, por sua vez, pode levar à resolução ou, segundo alguns autores, como JORGE MOSSET ITURRASPE, à imposição do dever de renegociar o contrato.

Como já afirmando anteriormente, a frustração do fim do contrato atinge a utilidade prática da prestação, ou seja, um elemento da causa final do contrato; não atinge a própria prestação (objeto do contrato), que permanece sendo possível.

Dito em outras palavras: na frustração do fim do contrato, a prestação ainda pode ser cumprida pelo devedor, porém já não mais interessa ao credor. Diferentemente, nas hipóteses de caso fortuito ou força maior, a própria prestação torna-se impossível, em razão da perda ou deterioração da coisa.

Por outro lado, enquanto a frustração do fim do contrato configura uma hipótese de impossibilidade relativa de cumprimento da prestação, no caso fortuito ou força maior, tal impossibilidade é absoluta. De fato, conquanto o fim do contrato possa estar frustrado, nada impede que a prestação ainda possa ser cumprida. No caso suprarreferido da diligência Paris-Rouen, por exemplo, embora o fundamento da decisão proferida pelo Tribunal francês tenha sido a ocorrência de caso fortuito ou força maior, é certo que a construção da ferrovia entre as duas cidades, por si só, não impedia a execução do contrato. O serviço de transporte por carruagem que levava três dias para completar o percurso entre Paris e Rouen ainda poderia ser mantido, já que havia 
cavalos, carruagens, coxos e a estrada por onde passavam as carruagens não havia sido destruída.

Sucede que, com o advento da estrada de ferro, o mesmo itinerário passou a ser realizado em meio-dia. E tal evento fez com que a exploração do serviço de diligências entre as duas cidades perdesse o seu propósito prático, elemento integrante da causa final do contrato. Caso típico de frustração do contrato, portanto.

Por outro lado, são hipóteses de caso fortuito (ou força maior) os casos Paradine vs. Jane e Taylor vs. Caldwell, referidos acima.

Insta destacar mais uma vez que, no sistema da Common Law, até o julgamento do caso Taylor vs. Caldwell, o princípio da força obrigatória dos contratos era tão absoluto, que nem mesmo nas hipóteses de caso fortuito ou força maior provocado pela ação do homem, permitia-se a liberação do devedor.

Também são hipóteses de impossibilidade absoluta (por superveniência de lei ou ato normativo), equiparáveis à ocorrência de caso fortuito e força maior, os casos da Espanha, sendo certo que os danos decorrentes do novo Plano de Ordenações de Barcelona (caso 1) eram efetivamente de ser imputados aos arquitetos, que estavam em mora (como prevê, por exemplo, o art. 248 do nosso Código Civil ${ }^{47}$ ).

\subsubsection{Frustração do fim do contrato e excessiva onerosidade superveniente (teoria da imprevisão).}

Os dois institutos aproximam-se, na medida em que configuram hipóteses de impossibilidade relativa do contrato (e não absoluta).

Contudo, nas hipóteses de onerosidade excessiva superveniente (como v.g. na teoria da imprevisão acolhida pelo art. 478 do Código Civil), não há perda da finalidade prática do contrato: o cumprimento da prestação torna-se extremamente oneroso para uma das partes.

Enquanto a frustração do fim do contrato atinge a causa final do negócio, isto é, o propósito prático que as partes tinham em mira ao celebrá-lo, a excessiva onerosidade

\footnotetext{
47، Art. 248. Se a prestação do fato tornar-se impossível sem culpa do devedor, resolver-se-á a obrigação; se por culpa dele, responderá por perdas e danos."
} 
superveniente atinge o equilíbrio econômico do contrato $^{48}$ (ou seja, o equilíbrio entre prestação e contraprestação).

Nesses termos, fica claro, por exemplo, que o caso do aguardente de beterraba, mencionado acima, configura, na realidade, hipótese de excessiva onerosidade superveniente ao contrato e não de frustração do fim do contrato.

E, por último, vale destacar ainda que a frustração do fim do contrato não exige, como requisito para a sua aplicação, a imprevisibilidade do evento, diversamente do que ocorre com a excessiva onerosidade superveniente (cf. art. 478 do Código Civil) ${ }^{49}$.

\subsubsection{Frustração do fim do contrato e erro.}

Pode-se dizer que, tanto na frustração do fim do contrato quanto no erro, há um desconhecimento ou certo equívoco quanto às reais circunstâncias que envolvem o vínculo contratual.

Contudo, a frustração do fim do contrato opera no plano da eficácia dos negócios jurídicos, conduzindo à resolução do contrato.

Já, o erro, como se sabe, é um vício do consentimento, sendo, assim, causa de invalidade dos negócios jurídicos. Interfere negativamente no plano da validade do contrato, tornando-o írrito.

Precisamente por ser uma causa de invalidade do negócio jurídico, o erro incide já no momento da formação do vínculo contratual e alcança o objeto do contrato. Na

\footnotetext{
${ }^{48}$ EbKe, Werner F. \& STEINHAUeR, Bettina M. The Doctrine of Good Faith in German Contract Law. In: BEATSON, Jack and FRIEDMANN, Daniel. (Ed.). Op. cit., p. 183: “(...) the doctrine of frustration of purpose (Zweckstörung) applies to cases in which performance is still possible, but in which the creditor has lost interest in the performance. Thus, the rules of impossibility normally do not aply, nor does the doctrine of Wegfall der Geschäftsgrundlage when the buyer has lost interest, because an event has occurred which frustrated his assumption that he would gain profit from further selling the goods he contracted for. In such a case, the purpose of the contract is not frustrated; rather, the frustration relates to the profits to be made from transactions. One could also argue that the buyer has assumed the risk of mistake with respect to the use of goods." (Em tradução livre do autor: "a doutrina da frustração do contrato aplica-se a casos em que a execução ainda é possível, mas o credor perdeu o interesse na execução. Assim, as regras da impossibilidade não são aplicáveis, como também não é a doutrina da base objetiva do negócio, porque ocorreu um evento que frustrou a impressão que ele tivera de que obteria lucro com as vendas posteriores dos bens que adquiriu. Nesse caso, o fim do contrato não resta frustrado; ao revés, a frustração atinge os lucros a serem obtidos com transações futuras. Pode-se dizer que o comprador assume o risco pelo erro a respeito da utilização dos produtos").

${ }^{49}$ Vale lembrar que o art. $6^{\circ}, \mathrm{V}$, do Código de Defesa do Consumidor não restringe a aplicação da teoria da excessiva onerosidade superveniente aos casos em que o evento perturbador da economia do contrato seja imprevisível (como preconiza a teoria da imprevisão, nos termos do art. 478 do Código Civil).
} 
frustração do fim do contrato, passa-se de modo diverso: o evento só surge na fase da execução do contrato e, como já demonstrado, atinge não o objeto, mas a causa final do negócio.

\subsubsection{Frustração do fim do contrato e vício redibitório.}

Tampouco se confunde a frustração do fim do contrato com o vício redibitório. A semelhança entre os dois institutos reside em que, tanto em um, quanto em outro, uma das prestações do contrato resulta inútil, sem que de tal inutilidade prática tenha ciência a parte prejudicada.

Assim é que, por exemplo, na compra-e-venda de um automóvel, se o comprador verifica que há um defeito oculto nos freios, certamente retornará à concessionária, para, nos termos do art. 18 do Código de Defesa do Consumidor, exigir a substituição do veículo por um outro, do mesmo modelo; rescindir o contrato, e exigir a restituição do preço pago pelo veículo, ou pleitear o abatimento do preço ${ }^{50}$.

Como se percebe, a prestação da concessionária - consistente na entrega do automóvel, inclusive com o pertinente registro no departamento de trânsito - ter-se-á tornado inútil, porque de nada adianta ao consumidor receber um automóvel cujos freios não funcionam.

A inutilidade prática da prestação também é uma nota característica da frustração do fim do contrato, mas há, pelo menos, dois grandes traços distintivos que a separam completamente do vício redibitório.

Em primeiro lugar, nos vícios redibitórios, a inutilidade prática da prestação decorre de circunstâncias intrínsecas da coisa (é um defeito da coisa), enquanto que, na

\footnotetext{
50 “Art. 18. Os fornecedores de produtos de consumo duráveis ou não duráveis respondem solidariamente pelos vícios de qualidade ou quantidade que os tornem impróprios ou inadequados ao consumo a que se destinam ou thes diminuam o valor, assim como por aqueles decorrentes da disparidade, com a indicações constantes do recipiente, da embalagem, rotulagem ou mensagem publicitária, respeitadas as variações decorrentes de sua natureza, podendo o consumidor exigir a substituição das partes viciadas. $\S 1^{\circ}$ Não sendo o vício sanado no prazo máximo de trinta dias, pode o consumidor exigir, alternativamente e à sua escolha: I - a substituição do produto por outro da mesma espécie, em perfeitas condições de uso; II - a restituição imediata da quantia paga, monetariamente atualizada, sem prejuízo de eventuais perdas e danos; III - o abatimento proporcional do preço."
} 
frustração do fim do contrato, a inutilidade prática da prestação deriva de circunstâncias externas, alheias ao estado da coisa.

Por outro lado, os vícios redibitórios, tal como sucede com o erro, já existem desde o momento da celebração do ajuste, diferentemente da frustração do fím do contrato, que ocorre no momento da execução do negócio.

Outra diferença essencial entre as duas figuras é a produção de efeitos: o vício redibitório gera o direito à revisão ou à rescisão do negócio jurídico (artigos 441 e 442 do Código Civil); a frustração do fim do contrato acarreta a resolução do ajuste.

\subsubsection{Frustração do fim do contrato e lesão.}

A lesão, prevista no art. 157 do nosso Código Civil, pode ser definida, em apertada síntese, como o desequilíbrio econômico originário entre a prestação e a contraprestação do contrato, que gera à parte prejudicada o direito de rescindir o contrato. Sendo um vício social, leva à invalidade do negócio jurídico.

A frustração do fim do contrato, como já demonstrado, nada tem que ver com o desequilíbrio econômico do contrato, mas sim com a perda da sua utilidade prática. Ademais, sempre decorre de um fato superveniente, que implica a ineficácia (e não a invalidade) do contrato.

\subsubsection{Frustração do fim do contrato e inexigibilidade (Unzumutbarkeit).}

Como causas que são de ineficácia e extinção da relação contratual, ambas essas figuras estão muito próximas, sendo difícil precisar a fronteira entre uma e outra.

De qualquer modo, a diferença se torna visível se se atentar para que, na frustração do fim do contrato, o ponto central é o desaparecimento da utilidade prática da prestação, enquanto que, na inexigibilidade, o que ocorre é a inviabilidade econômica da manutenção do contrato para uma das partes, inviabilidade essa que a nenhuma delas possa ser imputada. Assim, por exemplo, os casos da coroação supracitados são típicas hipóteses de frustração do fim contrato, enquanto, de outro 
lado, o caso das sacas de farinha, julgado pelo Reichsgericht em $1904^{51}$, configura uma típica hipótese de aplicação da teoria da inexigibilidade.

É certo, entretanto, que há “casos limítrofes”, nos quais a distinção não se revela tão fácil, v.g., no caso Alerse S.R.L. c. Carrefour Argentina S/A, mencionado acima. Ali, a situação em apreço enquadrar-se-ia na inexigibilidade, porquanto mais do que a utilidade prática da prestação, o fator que determinou, decisivamente, a extinção do contrato foi a inviabilidade econômica do contrato, inimputável às partes. Na realidade, esta é que causou aquela.

O mesmo se pode dizer do caso José Morandera S.A c. Nobleza Piccardo S.A., que girou em torno da inviabilidade econômica (naquela hipótese, imputável a um terceiro, concorrente da ré) do contrato de distribuição comercial celebrado entre as partes.

No caso das diligências Paris-Rouen, supracitado, o que se percebe é que a própria utilidade prática do contrato desaparecera, a partir do momento em que o trajeto entre as duas cidades passou a ser realizado pelos trens em tempo muito inferior ao que era despendido com as carruagens. Assim, a viabilidade econômica do contrato é que foi afetada pela perda da utilidade prática do contrato e não o inverso.

\subsubsection{Frustração do fim do contrato e obtenção do propósito prático por outros meios.}

Figura simétrica à frustração do fim do contrato é a obtenção do resultado prático por outros meios. Nesse caso, o interesse prático de uma das partes simplesmente não é satisfeito pela prestação contratual, mas por fatos diversos.

Tais fatos podem ser naturais (por exemplo, uma empresa é contratada para desencalhar um barco, mas, pouco tempo depois, a maré sobe, removendo-o do banco de areia; uma empresa é contratada para a demolição de um edifício que é destruído por um terremoto) ou praticados por terceiros estranhos ao contrato (por exemplo, alguém doa ao comprador uma obra de arte que este pretendia adquirir do vendedor; o químico compromete-se a produzir um novo produto e, no decorrer da execução do contrato, outros químicos descobrem a fórmula desejada). ${ }^{52}$

\footnotetext{
${ }^{51}$ Cf. item 2.1.

${ }^{52}$ Gianfelici, Mário César. Op. cit., p. 108.
} 


\section{Quaestio Iuris}

Como se percebe, na obtenção do propósito prático por outros meios, o interesse de uma das partes simplesmente desaparece, como ocorre na frustração do fim do contrato. Contudo, enquanto naquela, o interesse da parte não resta satisfeito, nesta, ao revés, ocorre o inverso: a parte obtém a utilidade prática visada. ${ }^{53}$

A doutrina não revela qual seria o efeito da obtenção do propósito prático por outros meios.

GIANFELICI considera que se a prestação ainda é realizável, a parte (credor) que teve o seu interesse satisfeito por outro meio, diverso do cumprimento da prestação devida, deve cumprir com a prestação que lhe incumbe.

Diferentemente, para os casos em que a prestação já se revela irrealizável, a solução dependeria, segundo GIANFELICI, da natureza do fato que ensejou a satisfação da parte. Se casual, como na hipótese do desencalhe da embarcação, a solução seria remeter-se às regras atinentes à distribuição dos riscos contratuais, pois se o devedor assume o risco da impossibilidade da prestação, nada mais justo do que se beneficiar do resultado esperado pelo credor. ${ }^{54}$

Se, ao contrário, o fato que acarretou a satisfação do credor não fosse casual (v.g., na hipótese da doação da obra de arte ao interessado na compra-e-venda desta), não seria dado ao devedor, por força do princípio da vedação do enriquecimento sem causa, receber a contraprestação devida, mas este faria jus ao reembolso das despesas porventura efetuadas para a execução do contrato.

\subsection{Efeitos da frustração do fim do contrato.}

Conseqüência da frustração do fim do contrato é a respectiva resolução. ${ }^{55}$

\footnotetext{
${ }^{53}$ Ibidem, p. 109.

${ }^{54}$ Infelizmente, não é possível, nesse ponto, concordar com o Mestre argentino: tal solução consagraria o enriquecimento sem causa do devedor, que, sem esforço algum, perceberia o valor da prestação a cargo do credor (art. 884 do Código Civil).

55 Para JORGE Mosset ITURRASPE, a frustração do fim do contrato, em regra, conduz à ineficácia do contrato, mas pode também determinar a auto-adaptação ou autorrevisão do contrato pelas próprias partes $^{55}$, ou seja, à renegociação do contrato (ITURRASPE, Jorge Mosset; FALCóN, Enrique M.; PIEDECASAS, Miguel. A. La frustrácion del contrato y la pesificación, p. 117). Tal entendimento, contudo, não se compadece com a própria natureza do instituto: a frustração do fim do contrato é uma hipótese de impossibilidade relativa do contrato, tal qual, a inexigibilidade (Unzumutbarkeit), e, por isso, conduz necessariamente à ineficácia do contrato.
} 
Quaestio Iuris

vol.05, $\mathrm{n}^{\mathrm{o}}$ 02. ISSN 1516-0351

Tradicionalmente, a resolução conduz às partes ao status quo ante. Nesses termos, o credor deixa de perceber a prestação, sem direito a perdas e danos, e o devedor, por sua vez, fica exonerado da responsabilidade pelo cumprimento da obrigação.

É bem de ver-se, entretanto, que a resolução do contrato nesses moldes não se compagina com a teoria da frustração do fim do contrato.

Em primeiro lugar, a frustração do fim do contrato alcança apenas os contratos cuja execução avance no tempo.

Pois bem. É justamente nos contratos cuja execução se protrai no tempo que se realizam os maiores investimentos. Tais contratos geralmente giram em torno de operações econômicas de maior monta e intensidade. Com efeito, nos contratos de execução instantânea, não há dispêndio ao longo do tempo: a operação econômica subjacente normalmente é muito simples e imediatamente quantificável em termos pecuniários.

É claro que há exceções. Basta pensar-se que um contrato de empreitada (típico contrato de execução diferida) pode envolver valores relativamente baixos (v.g., reforma de um cômodo em uma pequena casa), enquanto que a compra-e-venda de um automóvel, muitas vezes, pode se dar em contrapartida a um preço milionário (v.g., a compra de uma bela Ferrari vermelha). Mas a regra geral é: as operações econômicas mais prolongadas envolvem maior dispêndio de recursos e maiores investimentos.

Por isso mesmo, não há como pretender-se que a resolução do vínculo contratual causada pela frustração do fim do contrato conduza simplesmente à extinção do contrato, sem se tomar em consideração os gastos e investimentos realizados pela outra parte. $^{56}$

Impõe-se, nesses casos, que a parte prejudicada pela frustração do fim do contrato reembolse as despesas e os investimentos realizados pelo outro contraente.

Note-se, mais uma vez, que apesar de garantir ao devedor o direito potestativo de denunciar o contrato, por força da inexigibilidade do contrato (Unzumutbarkeit), o $\S$ 314 , n.1, do BGB, estabelece que o credor pode exigir uma indenização do devedordenunciante.

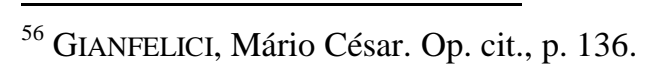


Essa mesma solução deve ser adotada nos casos que envolvam a frustração do fim do contrato, especialmente porque a inexigibilidade e a frustração do fim do contrato possuem um ponto em comum: a perturbação da finalidade prática do vínculo obrigacional (e não da equação econômica do contrato, isto é, do balanço entre prestação e contraprestação, como sucede nos casos de excessiva onerosidade superveniente). ${ }^{57}$

\section{Comentários finais: uma ressalva necessária.}

Ao longo deste estudo, procuramos demonstrar que o alargamento do conceito de impossibilidade no direito das obrigações - expresso nas figuras da frustração do fim do contrato e da inexigibilidade - oferece uma série de soluções práticas para graves problemas que estão na ordem do dia.

A realidade econômica da sociedade pós-moderna, caracterizada pela profusão dos contratos de longa duração, exige profunda reflexão sobre as tradicionais regras de distribuição dos riscos do contrato.

Todavia, o papel do debate sobre a frustração do fim do contrato e a inexigibilidade é abrir portas para a reconstrução e não para a destruição da dogmática contratual.

O presente estudo não deve ser visto como mera crítica ao princípio da força obrigatória dos contratos, que é essencial para a segurança dos negócios.

A doutrina pós-positivista, obcecada pelas cláusulas gerais, em vez de reformular o princípio, simplesmente o deixou "fora de moda": conferiu desmedido peso ao método legislativo das cláusulas gerais, deu ao "princípio da razoabilidade" dimensão exagerada, e fez da "ponderação de interesses" remédio para todos os males jurídicos possíveis e imagináveis.

Por isso mesmo, o alargamento da impossibilidade obrigacional não pode ser visto como panacéia: numa época em que quase tudo é deixado ao "bom senso" do intérprete, um pouco de segurança jurídica faz muito bem.

\footnotetext{
${ }^{57} \mathrm{Na}$ mesma ordem de ideias, o preceito inserto no art. 473, parágrafo único do Código Civil estabelece que dada a natureza do contrato, se uma das partes houver feito investimentos consideráveis para a sua execução, a denúncia unilateral só produzirá efeito depois de transcorrido tempo compatível com a natureza e o vulto dos investimentos.
} 
Quaestio Iuris

vol.05, $\mathrm{n}^{\circ}$ 02. ISSN 1516-0351 


\section{Referências:}

Aguiar JR., Ruy Rosado de. Extinção dos Contratos por Incumprimento do Devedor - Resolução (de acordo com o Novo Código Civil). 2. ed. (rev. e atual.). Porto Alegre: Aide, 2004.

Alves, José Carlos Moreira. O favor debitoris como princípio geral de direito. In: Revista Brasileira de Direito Comparado, $n^{\circ}$ 26, p. 03-23, $1^{\circ}$ semestre, 2004.

ATYIAH, Patrick. The rise and fall of freedom of contract. Oxford: Clarendon Press, 1979.

Azevedo, Antônio Junqueira de. Natureza jurídica do Contrato de consórcio. Classificação dos atos jurídicos quanto ao número de partes e quanto aos efeitos. Os contratos relacionais. Contratos de duração. Alteração das circunstâncias e onerosidade excessiva. Sinalagma e resolução contratual. Resolução parcial do contrato. Função social do contrato. Revista dos Tribunais, São Paulo, v. 807, p. 113-137, fev. 2005.

Saraiva, 2000.

Negócio Jurídico: Existência, Validade e Eficácia. São Paulo,

Chen-Wishart, Mindy. Consideration: Practical Benefit and the Emperor's New Clothes. In: BeAtson, Jack and Friedmann, Daniel. (Ed.). Good Faith and Fault in Contract Law. Oxford: Clarendon Press, 1995, reprinted in 2002, p. 123-150.

Cogo, Rodrigo Barreto. A frustração do fim do contrato. 2005. 287 f. Dissertação (Mestrado em Direito Civil) - Universidade de São Paulo, São Paulo, 2005.

CordeIro, Antônio Manuel Menezes. Da boa-fé no Direito Civil. Coimbra: Almedina, 2001.

A Modernização do direito das obrigações. Revista da Ordem

dos Advogados de Portugal, vol. II, abr./2002. Disponível em: http://www.oa.pt/Conteudos/Artigos/detalhe_artigo.aspx?idc=31559\&idsc $=13744 \&$ ida $=13767$. Acesso em 15.09.2006.

EbKe, Werner F. \& Steinhauer, Bettina M. The Doctrine of Good Faith in German Contract Law. In: Beatson, Jack and Friedmann, Daniel. (Ed.). Good Faith and Fault in Contract Law. Oxford: Clarendon Press, 1995 (reprinted in 2002), p. 171-190.

FIKENTSCHER, Wolgang. Schuldrecht. 9. Durchgesehene und Ergänzte Auflage. Berlin: Walter de Gruyter, 1997.

GAVAZZONI, Adriana. A renegociação e a adaptação do contrato internacional. 1. ed. Curitiba: Juruá, 2006. 
GiANFELICI. Mario Cesar. La frustración del fin del contrato. 1. ed. Buenos Aires: Hammurabi, 2004.

GOMES, Orlando. Obrigações. 6 ed. Rio de Janeiro: Forense, 1981.

ItURRASPe, Jorge Mosset. Contratos conexos. Grupos y redes de contratos. Buenos Aires: Rubinzal-Culzoni, 1999.

ItUrRaspe, Jorge Mosset; FAlCón, Enrique M.; PiedeCASAS, Miguel. A. La frustrácion del contrato y la pesificación. Buenos Aires: Rubinzal-Culzoni, 2002.

LARENZ, Karl. Base del negocio jurídico y cumplimiento de los contratos (traducción de Carlos Hernandez Rodriguez). Madrid: Editorial Revista de Derecho Privado, 1956.

LoREnZ, Werner. Contract Modification and Change of Circumstances. In: BEATSON, Jack \& Friedmann, Daniel (Ed.). Good Faith and Fault in Contract Law. Oxford: Clarendon Press, 1995 (reprinted in 2002), p. 357-376.

Miranda, Francisco Cavalcanti Pontes de. Tratado de Direito Privado, tomo VI. Rio de Janeiro: Borsoi, 1957.

Moraes, Maria Celina Bodin de. O procedimento de qualificação dos contratos e a dupla configuração do mútuo no direito civil brasileiro. Revista Forense, vol. 309, p. 33-61, 1990.

A causa dos contratos. Revista Trimestral de Direito Civil, Rio de Janeiro, v. 21, p. 95-120, jan./mar. 2005.

MotA, Maurício. A proteção decorrente do favor debitoris como princípio geral do direito das obrigações no ordenamento jurídico brasileiro. Quaestio Iuris, v. 3, p. 49$108,2006$.

Mousseron. Jean Marc. La gestion des risques par le contrat. In: Revue Trimestrielle de Droit civil, n. 3. Paris: Sirey, Juillet/Septembre 1988, p. 481-504.

NELLE, Andreas. Neuverhandlungspflichten: Neuverhandlungen zur Vertragsanpassung und Vertragsergänzung als. Gegenstand von Pflichten und Obliegenheiten. München: C.H.Beck’sche, 1994.

OPPO, Giorgio. I contratti di durata. In: Scriti giuridici, Padova: CEDAM, 1992, vol. III, p. 206-243. 
Quaestio Iuris vol.05, $\mathrm{n}^{\mathrm{o}}$ 02. ISSN 1516-0351

Tepedino, Gustavo; Barboza, Heloísa Helena; e Moraes, Maria Celina Bodin de. Código Civil Interpretado conforme a Constituição da República: Parte Geral e Obrigações (arts. $1^{\circ}$ a 420). 1. ed. Rio de Janeiro: Renovar, 2006. 